\title{
Use of groin flap in the closure of through and through defect of a forearm: A case report
}

\author{
Chenicheri Balakrishnan MD, Thomas A Pane MD, Abdullah J Khalil MD
}

C Balakrishnan, TA Pane, AJ Khalil. Use of groin flap in the closure of through and through defect of a forearm: A case report. Can J Plast Surg 2004;12(1):47-48.

The groin flap is a vascularized axial flap based on the superficial circumflex iliac artery arising from the femoral artery just below the inguinal ligament. It is used regularly by many reconstructive surgeons for covering soft tissue defects of the hand. Although the development of various fasciocutaneous free flaps during the 1980s decreased the attractiveness of the groin flap, these flaps can be used in reconstructing significant defects of the forearm and hand where free tissue transfer is not feasible.

Key Words: Groin flap

Q econstruction of soft tissue defects involving the affected Rextremity is not easy when there is vascular compromise. Although free tissue transfer is routinely used as a single stage procedure, the lack of healthy vessels make these procedures technically impossible. Flaps from the chest, abdomen and groin could be fashioned to close upper extremity defects in stages based on the musculocutaneous perforators. We report the use of a groin flap for reconstruction of defects of flexor and extensor aspect of the forearm following revasularization of the hand with a vein graft.

\section{CASE PRESENTATION}

A 19-year-old man who sustained a close range high-energy gunshot wound to the right forearm presented with fractures of both forearm bones, loss of both flexor and dorsal soft tissue and neurovascular compromise of the hand. His other injuries included gunshot wounds to the right side of the chest and left femur. He underwent plating of his ulna, and, because there was significant loss of the radius, external fixation of the radius. He underwent vein grafting of his radial artery to revascularize the hand, and his ulnar nerve and median nerve were tagged due to loss of nerve tissue. This left soft tissue defects over the flexor and extensor aspect of the forearm extending between the radius and ulna side through which two fingers could be passed (Figure 1).

Because this was a high-energy gunshot wound with significant comorbid factors, free tissue transfer was not feasible. A decision was made to cover the defect using a groin flap and a cable graft for the nerve. The flap was elevated and passed through the interosseous membrane after de-epithelializing the

\section{Rapport de cas d'utilisation d'un lambeau inguinal pour la correction d'une plaie traver- sant l'avant-bras}

\begin{abstract}
Le lambeau inguinal est un lambeau axial vascularisé basé sur l'artère iliaque circonflexe, rameau de l'artère fémorale, juste sous le ligament inguinal. Les chirurgiens qui travaillent en reconstruction l'utilisent régulièrement pour corriger les anomalies affectant les tissus mous de la main. Bien que le développement de divers lambeaux libres fasciocutanés au cours des années 1980 ait rendu le lambeau inguinal moins attrayant, ce dernier peut néanmoins être utilisé pour la reconstruction d'anomalies importantes à l'avant-bras et à la main où il est impossible de transférer des tissus libres.
\end{abstract}

buried segment to cover the extensor side (Figure 2). The surrounding open areas were closed using a split thickness skin graft and the upper extremity was immobilized using an abdominal binder. The flap was divided at 18 days. He underwent sural nerve grafting of the median and ulnar nerves. The fracture went on to heal following bone grafting of the radius.

\section{DISCUSSION}

Studies carried out on the angiosomes have helped reconstructive surgeons in designing flaps based on blood supply. The skin of the chest, abdomen and groin are supplied by a number of perforator vessels. The deep epigastric arcade forms the abdominal portion of a ventral vascular network linking the subclavian and external iliac arteries. This network forms the basis of various axial flaps used in reconstructive surgery. The groin flap is an axial pattern flap based on the superficial circumflex iliac artery and the superficial venous network of the groin area. The superficial circumflex artery commonly arises from the femoral artery and in about $50 \%$ of cases there will be a common trunk with the superficial inferior epigastric artery. The point of origin lies approximately three centimeters below the mid-inguinal point. McGregor and Jackson (1) first reported this flap as a pedicled skin flap. This flap has been used as a free flap by O'Brien et al (2) and modified as the free iliac flap with a lateral skin island by Acland (3).

Being an axial pattern flap, the groin flap can reliably be raised with good length-to-breadth ratio. The donor site scar lies in a cosmetically advantageous position. The venous drainage is through a superficial set, which drains into the saphenous system. The deep venae comitantes are a less 


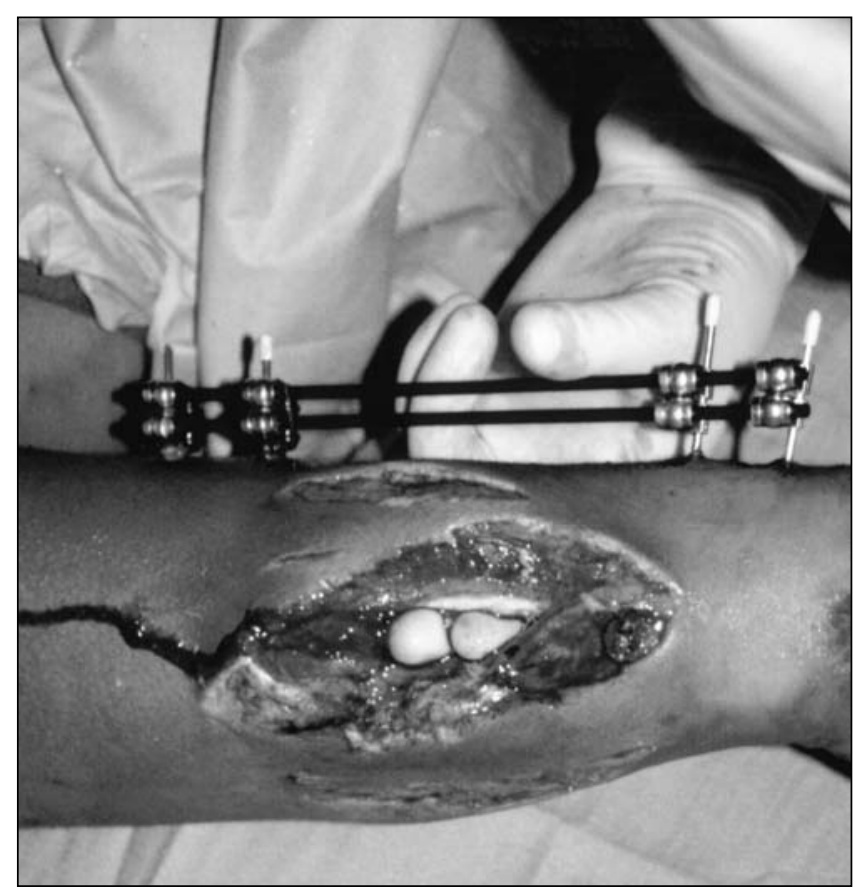

Figure 1) Defect of the forearm through which two fingers can be passed

important route of drainage and may also join the saphenofemoral junction or may pass deeply beneath the femoral artery to enter the femoral vein.

The pedicle flap principle initiated in the pre-Christian era has been refined, and forms the fundamental basis for the development of reconstructive surgery. Although groin flaps are used by many reconstructive surgeons for soft tissue defects of the hands when free tissue transfer is not feasible, the positioning causes edema of the hand and the flap is usually bulky and requires revision.

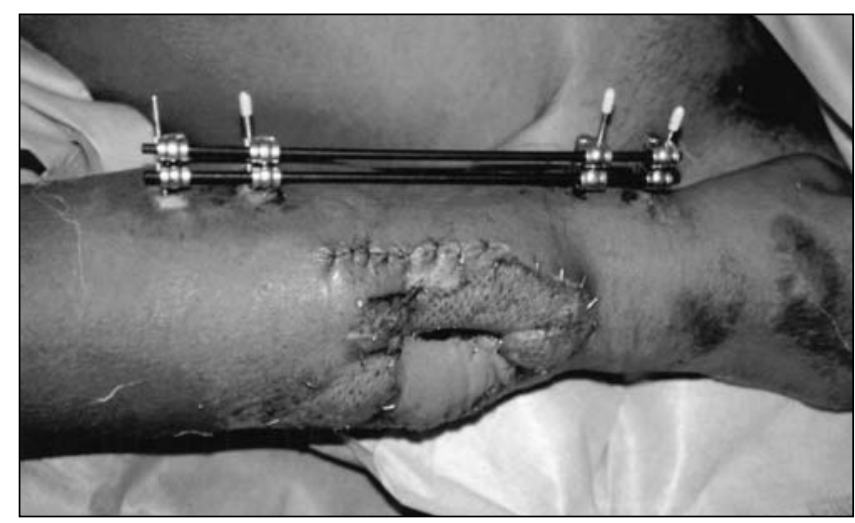

Figure 2) Groin flap in place before division

In this patient there was loss of bone, segmental loss of median nerve, injuries to ulnar nerve, radial and ulnar arteries and soft tissue defect, which extended through the interosseous membrane. The defect was wide enough to admit two fingers through the interosseous membrane. To prevent damage to the reconstructed arterial system, soft tissue reconstruction was carried out using a groin flap passed to the extensor surface of the forearm through the interousseous space. This case report demonstrates the versatility of the groin flap in closing complex defects of the forearm.

\section{REFERENCES}

1. McGregor IA, Jackson IT. The groin flap. Br J Plast Surg 1972;25:3-16.

2. O'Brien B, Ma C, Macleod AM, Hayhurst JW, Morrison WA. Successful transfer of a large island from the groin to the foot by microvascular anastomosis. Plast Reconstr Surg 1973;52:271-278.

3. Acland RD. The free iliac flap. A lateral modification of the free groin flap. Plast Reconstr Surg 1979;64:30-6. 